Irina Černâkova

Pietrozawodsk, Russia

\title{
Vodlozerie (North-West Russia): former social potential in the light of historical data and geographical landscape
}

\section{Introduction}

The Vodlozero region is an area of early peasant settlement in the Russian North. It is located to the northeast of the Lake Onego, surrounding the rather large Lake Vodlozero - one of the four largest water reservoirs in southern Karelia (Northwest Russia). The watershed between the two lakes forms a natural eastern border of the region. From the south and north its borders were defined by the settlement areas of the Russians, who identified themselves as "Vodlozery", i.e. inhabitants of Vodlozerie and not any other historical or cultural province. ${ }^{1}$

Interestingly, the region's remoteness from cultural and economic centers had more influence on its development in modern times than during Middle Ages. A system of Vodlozerie settlements within the borders of "boyarshchina" - feudal lands of Novgorod people - existed here and was well documented in the cadastral sources as early as in the middle of the $16^{\text {th }}$ century, and furthermore it was preserved almost unchanged up until the $20^{\text {th }}$ century. Since the $18^{\text {th }}$ century the region has become more and more isolated. The reason for this isolation is believed to be the shift of the trade routes towards the new capital of Saint Petersburg as well as the almost complete absence of roads. ${ }^{2}$ Indeed, there were never built any asphalt roads leading to the Vodlozero region. The settlements were mostly located on the islands in Lake

\footnotetext{
${ }^{1}$ Valentina Kuznecova, Boris Putilov, ed., Pamâtniki russkogo fol'klora Vodlozer'â: Predaniâ i bylički (Pertozavodsk 1997), 105-106, 107-110, 111.

${ }^{2}$ Konstantin Aver'ânov, "Vodlozer'e - Zapovednyj kraj russkogo Severa”, Trudy Instituta Rossijskoj Istorii 9 (2010): 490-491, 498.
} 
Vodlozero and sometimes along its shores (see Figure 1). It should be emphasized that the then established system of settlements seemed perfect for the utilization of the local fields, fishery and forestry. For centuries the Vodlozero region represented an example of harmonious coexistence of man and nature. In pre-revolutionary times every settlement's inhabitants secured quite enough sustenance through cultivation of surrounding arable fields, a significant part of which were "slash-and-burn" plots in the forest, as well as by utilizing all available pasture. Fishing, hunting, collecting firewood and the timber trade also helped to support the local society. Nature itself defined the optimal variety of economic activity and set a limit to it.

The Vodlozero region is characterized by a specific local cultural tradition, deriving from this territory's remoteness and inaccessibility. It was a "lone bear's den" - even for the not particularly densely populated northwestern part of Russia. The indigenous inhabitants of the region still identify themselves with its name, keeping in mind their common settlement territory and peculiarities of the local dialect as well as recognizing their shared feeling of unity, derived from the idea of common Novgorod origins. ${ }^{3}$ It is acknowledged in historiography that their small numbers did not prevent Vodlozerie inhabitants from forming a special ethnic group of Russians in Karelia. ${ }^{4}$ B. Sokolov - one of the researchers of the early $20^{\text {th }}$ century aptly characterised the colourful and original local culture, based on a diverse and distinct folk tradition, of Vodlozerie as "island = insular". ${ }^{5}$ It became subject to what is by now a rather comprehensive scientific literature, accompanied by numerous published original texts. ${ }^{6}$ At the same time, Vodlozerie - like any other Russian countryside - fully experienced the dramatic events of the $20^{\text {th }}$ century: Civil War, collectivisation, persecution of the richer peasants ("raskulachivanie"), labour duties at timber camps, and finally the liquidation of "unpromising" villages.

In 1991 the first national park in Northern Russia, and the largest in Europe, with a total area of 468,000 hectars, was established on the Vodlozerie territory. Accordingly, in the last decades of the $20^{\text {th }}$ century there were undertaken comprehensive studies of the local ethnography, folklore, toponymy, song tradition, dialect and history of the region, including the tradition of wooden architecture. ${ }^{7}$ Although the settlement structure was also investigated, it was only narratively described.

${ }^{3}$ Evgeniâ Cvetkova, Fol'klornaâ bylička Vodlozer'â: koldovstvo i magičeskaâ tradiciâ (Moskva 2014), accessed 2.09.2016, http://www.ruthenia.ru/folklore/au_tsvetkoval.htm.

${ }^{4}$ Konstantin Loginov, Etnolokal'naâ gruppa russkih Vodlozer'â (Moskva 2006), 249.

${ }^{5}$ Boris Sokolov, "Poèziâ Vodlozera: Iz zapisok issledovatelâ", Čitatel' i Pisatel' 35 (1928): 5.

${ }^{6}$ See for details: Sof'â Lojter, “Obètnolokal'noj fol'klornoj tradicii Vodlozer'â", Râbininskie Čteniâ, 2015, accessed 2.09.2016, http://kizhi.karelia.ru/library/ryabininskiechteniya-2015/1570.html.

${ }^{7}$ Vâčeslav Kulikov, ed., Prirodnoe i kul'turnoe nasledie Vodlozerskogo nacional'nogo parka (Petrozavodsk 1995); Oleg Červâkov, ed., Nacional'nyj park "Vodlozerskij”: Prirodnoe raznoobrazie i kul'turnoe nasledie (Petrozavodsk 2001). 
Figure 1. Settlements of Vodlozerie



Source: Loginov, Konstantin. Tradicionnyj žiznennyj cikl russkih Vodlozer'â: obrâdy, obyčai ikonflikty. Moskva 2010, 11. 
Meanwhile, a new school in historiography has developed, the founder of which is rightfully considered to be Hansjorg Kuster, a German paleobotanist and professor at Hannover University, who published the book The Forest History in $1998 .{ }^{8}$ Since then many studies have acknowledged the history of interaction between man and nature as being important and relevant. Albrecht Leman's book About People and Trees. The Germans and Their Forest has also taken this particular approach. ${ }^{9}$ Even closer to our research interests is the angle applied in the book of Joachim Radkau, Wood. How a Natural Resource Writes History, published in $2007 .{ }^{10}$ It is known that the forest occupies a special place in German culture. However, few know that in Finnish culture and in Karelian, which is close to Finnish, as well as the culture of any people living in the north of Russia, the forests had from the ancient times been the main "provider" for the inhabitants, since the arable lands offered were very infertile. There were also very few fields that were naturally useful for this specific purpose. At the same time there is no research in Karelian historiography which would "socialize" the forest history not in terms of empty allegations, but rather based on statistical data about inhabitants of specific settlements, who actively utilized the forests to satisfy their everyday needs.

In 2001 the Vodlozero National Park was declared a UNESCO Biosphere Reserve. Such status is awarded to territories where human activity is carried out in harmony with the environment. In this context it is particularly important to apply an interdisciplinary approach to investigating the historic interaction between human society and the environment on the regional level. Based on the initiative of biologist Olli-Pekka Tikkanen (University of Eastern Finland, Joensuu), who became interested in the articles I had written on the development of settlement structure in Karelia, it was decided to carry out an interdisciplinary research to determine the degree of human intervention in the forest landscape surrounding the villages. We believed that this must have depended on the density of population (number of inhabitants) in the villages and, consequently, on the number of cattles. Although there are numerous verbal statements, no attempt to identify exact dependencies utilizing cartographic sources has been made in the available scientific literature on Karelia. Two Finnish authors, divided by almost a century, have approached a similar problem. ${ }^{11}$ Olli Heikinheimo investigated

\footnotetext{
${ }^{8}$ Hansjörg Küster, Istoriâ lesa. Vzglâd iz Germanii (Sankt Peterburg 2012).

${ }^{9}$ Albrecht Lehmann, Von Menschen und Bäumen. Die Deutschen und ihr Wald (Hamburg 1999).

${ }^{10}$ Joachim Radkau, Holz. Wie ein Naturstoff Geschichte schreibt (München 2007); Joachim Radkau, Priroda i vlast': Vsemirnaâ istoriâ okružaûsej sredy (Moskva 2014).

${ }^{11}$ Olli Heikinheimo, Kaskiviljelyksen vaikutus Suomen metsiin (Helsinki 1915); Jouni Aarnio, Kaskiviljelystä metsätöihin: tutkimus Pielisjärven Kruununmetsistä ja kruununmetsätorppareista vuoteen 1910 (Joensuu 1999).
} 
the slash-and-burn farming in different parts of Finland, but did not correlate its widespread application with the density of population. J. Aarnio, on the other hand, explored the population history of the state-owned forests in Finland, but his research covered only single households, not villages. Also in the late 1990s an article written by S. Ericsson, L. Ostlund and A.-L. Axelsson was published, in which the Swedish authors - although they realized the need to know how cattle grazing and timber industry of the $19^{\text {th }}$ century affected the forests - only referenced a few travelers' descriptions. ${ }^{12}$

The present article sets up the historical background for ongoing interdisciplinary research, which in the past five years has been carried out by the author and O.-P. Tikkanen, who is assessing the state of modern forests from a historical perspective (a forest can be considered as an archive, preserving the footprints of human impact). We believe that there is a unique, never before utilized, opportunity to validate visual observations made in the modern forests through historical socio-demographic documentary sources. Our earlier experience with the international project "Settlements and land use in White Sea Karelia in the $19^{\text {th }}-21$ st centuries: impact of the identified consequences" / "Maankäyttö- ja asutushistorian vaikutus metsämaiseman rakenteeseen ja niiden heijastumat nykyisyyteen: Läntinen Vienan Karjala 1800-2000" (2012-2014) showed that a comprehensive interdisciplinary approach makes it possible to reach more certain retrospective conclusions about the level of human activity impact on the natural forest landscape..$^{13}$ Most importantly, our research allowed us to make well-grounded conclusions about recovery mechanisms of forests and biocenosis in general as well as the time period required for it. In order to apply the suggested method, it is necessary to be able to study forest landscapes, which have previously been in active use, but which then, for various reasons, ceased being permanently inhabited. The conclusions derived in the northern Karelia Voknavolok area, which is today a part of Kostomuksha National Park, have already been presented at international conferences and published. ${ }^{14}$

${ }^{12}$ Staffan Ericsson, Lars Östlund, Anna-Lena Axelsson, "A forest of grazing and logging: Deforestation and reforestation history of a boreal landscape in central Sweden", New Forests 19 (2000): 227-240.

${ }^{13}$ See for detail: Irina Černâkova, Olli-Pekka Tikkanen, Rajmo Hejkkilâ, Starye dokumenty i sovremennoe sotrudničestvo v issledovanii rannej istorii okružaûsej sredy v Karelii, Materialy V meždunarodnoj konferencii po istoričeskoj geografii (18-21 maâ 2015 g., Sankt-Peterburg 2015), $61-65$.

${ }^{14}$ Olli-Pekka Tikkanen, Irina Chernyakova, Raimo Heikkila, "Vanished villages - imprint of traditional agriculture in forest landscape of Western White Sea Karelia", Trudy Karel'skogo Naučnogo Centra RAN 6 (2014): 148-156, accessed 21.05.2016, http://transactions.krc.karelia. ru/publ.php?plang=r\&id=12321; Harri Holtta, Olli-Pekka Tikkanen, Irina Chernyakova, Raimo Heikkila, "Reflections of cultural history in the forest landscapes of Western White Sea Karelia", 
Another important source for the research agenda suggested here are the forest maps, containing information about forest composition and tree types. Incidently, this kind of source was available to us for the territory of Vodlozerie. Our preliminary conclusions ${ }^{15}$ now await validation by the landscape investigations. The adequacy of the results strongly depends on detailed knowledge of historical realities introduced in this article. Our approach is comprised of an analysis of data derived from historical documents and sources (statistical data in conjunction with localization of the settlements) combined with the methods of landscape modelling based on forest maps and opportunities provided by the satellite images of the Earth.

In modern Russia, marketing and branding of specific territories are all instruments applied to solving tasks of regional management. The territorial brand is a collection of established positive associations which are meant to add to the attractiveness of the region as an object of investment and economic activity. In order to develop their potential, regions constantly need to attract investors, potential inhabitants, and tourists, as well as to form a clear and positive image of the territory. ${ }^{16}$ Environment-friendly tourism is currently a prioritized area of development in Vodlozerie. It is not possible for the region to utilize its full potential without detailed knowledge of the historical settlement structure as well as what characterized its inhabitants' economic activities during the times of prosperity. This article can be considered a significant contribution to the relevant knowledge base.

\section{Former character of the region as historians and ethnographers imagined it and recent changes}

The Vodlozero area, which is today a practically uninhabited territory covered by forests and wetlands, was a rather densely populated and economically developed region for five to six centuries - up until the first third of the $20^{\text {th }}$ century (see Figure 1).

Trudy Gosudarstvennogo Prirodnogo Zapovednika "Kostomukšskij” 1 (2015): 183-186. thatveely dominated in the Vodlozero area landscape 1. Vanished villages.

${ }^{15}$ Olli-Pekka Tikkanen, Irina Chernyakova, "Past human population history affects current forest landscape sturcture of Vodlozero National Park, Northwest Russia", Silva Fennica 48 (2014): 4. ID 1207, accessed 21.05.2016, https://www.researchgate.net/publication/279079261_ Past_human_population_history_affects_current_forest_landscape_structure_of_Vodlozero_ National_Park_Northwest_Russia.

${ }^{16}$ Tat'âna Ầ kubova, Anna Krûkova, "Territorial'nyj brending kak instrument razvitiâ regiona", Molodoj Učenyj, 21 (2014), accessed 2.09.2016. http://moluch.ru/archive/80/14255. 
According to Konstantin Loginov, the majority of known settlements in the region were first mentioned as early as in the cadastral documents (pistsovye knigi) of Andrei Likhachev (hereinafter Cadastre 1563) - the earliest preserved data source for the territory under study. The author draws particular attention to the cultural aspects of Vodlozero's history (chapels and their dedications, sorcerers/ wisemen and their lives, local legends and holy days of the church calendar) and references the toponymic conclusions of Irma Mullonen and the observations of researcher of folklore Natalia Chervyakova. ${ }^{17}$ Even more detailed insight into traditional rites and practices, with special attention to conflict situations in the lives of Vodlozero area inhabitants from birth to death, is contained in the book which the same author devoted to ethnographic study of the region. ${ }^{18}$

Supposedly, certain villages in the vicinity of Vodlozero lake are believed to have existed as early as the very end of the $15^{\text {th }}$ century, and would have been included in Yuri Saburov's hand-written cadastral description (pistsovoe opisanie) of 1496 which did not survive to the present day. By the time the next known Cadastre 1563 was composed, some of these villages were abandoned and turned into wasteland. However, the widespread populating of Vodlozerie and thus successful economic activities in the region can be rather confidently dated back to even earlier times. Convincing evidence of its full-fledged inhabitation since the $14^{\text {th }}$ century at least can be found in numerous entries in Cadastre 1563 acknowledging prior ownership by famous Novgorodian boyar families: Esipov, Gruzov, Isakov, Khudyakov and Grigoriev.

By the end of the $15^{\text {th }}$ century these original ancestral estates, comprised of large parts of the territory with numerous settlements, turned out to be fractured, with a number of villages split between different owners, as retrospectively evidenced by scribe Andrey Likhachev. This process took place over a long period of time and as a result of many cases of inheritance, dowry, co-ownership and all kinds of other transactions.

More than half a century has now passed since significant human activity and comprehensive daily use of natural resources by local village communities in this area came to a halt. According to the list of settlements of $1905^{19}$ (hereinafter Spisok 1905) there were several dozen villages inhabited by 3365 people (hereinafter both genders are included), where almost all persons were peasants (3301, 98\%) making

\footnotetext{
${ }^{17}$ Konstantin Loginov, Istoričeskaâ spravka o poseleniâh Vodlozer'â, accessed 21.05.2016, http://vodlozero.nubex.ru/ru/nauka/issledovanie-istorii/istoricheskaya-spravka.

${ }^{18}$ Idem, Tradicionnyj žiznennyj cikl russkih Vodlozer'â: obrâdy, obyčai i konflikty (Moskva 2010).

${ }^{19}$ Ivan Blagoveŝenskij, ed., Spisok naselennyh mest Oloneckoj gubernii po svedeniâm za 1905 god (Petrozavodsk 1907).
} 
use of local land, water resources and forests. ${ }^{20}$ Out of these numerous villages, today only four remain inhabited all the year round: Kuganavolok, Kevasalma, Bostilovo and Varishpelda. There are also a few seasonally inhabited villages around Lake Vodlozero: Mikhailovskaya (or Vachilovo), Kanzanavolok, Koskosalma and Pelgostrov. In summer, descendants of the previous owners live in the very few houses remaining at the sites of original settlements. Vodlozero National Park's blockposts Gostnavolok, Kalakunda and Novguda, which are all part of the local tourist infrastructure, should also be mentioned here as ocasionally inhabited.

In the Soviet period Vodlozerie settlements were governed by four rural councils (sel'ski sovet), as documented in the list of settlements of $1933^{21}$ (hereinafter Spisok 1933). The first was centered in the village of Kanzanavolok and consisted of 18 settlements (Kolgostrov, Mikhailovskaya, Koskosalma, Podgorie, Ongilova Gora, Kurgilovo, Varishpelda, Rahkoila, Gostnavolok, Kalakunda, Gumarnavolok, Ragunova, Putilova, Ilekskoe Ustie, Mari Ostrov, Polovinskaya, Iliinsky Pogost), the second in the village of Bolshoi Kuganavolok, with 14 settlements (Malyi Kuganavolok, Okhtom-Ostrov, Pelgostrov, Bykovskaya, Matkalahta, Bostilova, Kevasalma, Bolshaya Poga, Malaya Poga, Vygostrov, Ragnozero, Serdechkina Izbushka, Prechestenski Pogost), the third in the village of Pilmasozero, with 6 (Kelkozero, Goliyanitsy, Zagorie, Goliya Reka, Paezero) and the fourth in the village of Chuayla, with 8 (Velikostrov, Vavdipole, Vama, Anufrievskaya, Borovoi Porog, Vamski Porog, Kuzeostrov)..$^{22}$ These data, combined with the quantitative information from four more time periods, also provide evidence of the high demographic development potenial of the region.

One by one the settlements of the Vodlozero area started falling into decay and this process of degradation requires special investigation. Loginov's observations suggest that human losses in the wars of 1939-1945 became the decisive factor in the region's desolation. As evidenced by the inhabitants themselves, some villages lost all their men in combat. In Varishpelda, for example, only three widows with children remained after the war, ${ }^{23}$ while 10-20 years earlier in accordance with the list of settlements of $1926^{24}$ (hereinafter Spisok 1926), as with the Spisok 1933, it had consisted of 12 well-established households. ${ }^{25}$ Growing children needed education, which forced them to leave their homes, first to study on a weekly basis in the elementary boarding school, which was located in

\footnotetext{
${ }^{20}$ Spisok 1905, 248-251.

${ }^{21}$ Spisok naselennyh mest: po materialam perepisi 1933 g. (Petrozavodsk, 1935).

${ }^{22}$ Spisok 1933, 76-77.

${ }^{23}$ Loginov, Istoričeskaâ spravka.

${ }^{24}$ Boris Potapov, ed., Spisoknaselennyh mest Karel'skoj ASSR: po materialam perepisi $1926 \mathrm{~g}$. (Petrozavodsk, 1928).

${ }^{25}$ Spisok 1926, 103; Spisok 1933, 76.
} 
the relatively close village of Pelgostrov. Later on they moved for longer periods of time to more distant places, including Pudozh, Petrozavodsk, and even Leningrad, where they could continue their education, which in turn resulted in their finding a job, starting their own family and staying for good.

Therefore, it does not seem surprising that by the Act of 28.10.1957 Varishpelda was annexed to Koskosalma. In addition to Varishpelda, Koskosalma now included Podgorie with 59 inhabitants in 1933, Rakhkoila (50 people), Ongilova Gora (47 people), Kurgilovo (46 people) and Gostnavolok (19 people). ${ }^{26}$ It can be concluded that this policy of village consolidation was quite widespread. In result, close to the end of the 1960s, 31 villages of Vodlozerie (i.e. $66 \%$ of the historical settlements, inhabited for several centuries) officially ceased to exist. ${ }^{27}$

As it turned out, consolidation of some villages at the expense of the others did not help to prevent the region from depopulation and probably even contributed to it to some extent, since the relocated inhabitants received land plots that were not the most useable, for example, in Bolshoi Kuganavolok. These families experienced much personal drama, which influenced their future lives and changed the behavioral objectives of the following generations. Some inhabitants of the remaining villages lived there until the end of the 1980s and even 1990s; however as they left or passed away these settlements (Kolgostrov, Pelgostrov, Chuyala, Kanzanavolok) were never permanently inhabited again. At best, they became summer vacation destinations for city dwellers, descendants of the former inhabitants, or new village house owners.

\section{Research objectives, time frame and data sources}

In collaboration with Finnish scholars specializing in forestry and environmental studies, my objective is to identify the impact level of human economic activity on natural (primarily forest) landscapes retrospectively. ${ }^{28}$ Thus, detection and analysis of quantative socio-demographic data is very important. It is possible to determine the approximate level of exterminatory pressure on the forests based on the number of households, population and aggregated quantity of livestock on a mini-regional scale. In this connection we have another task, which is no less important: comparative analysis of the interrelationship between socio-demographic characteristics and

\footnotetext{
${ }^{26}$ Loginov, Istoričeskaâ spravka.

${ }^{27}$ See for details: Irina Černâkova, "Vodlozer'e - poselenčeskie landšafty isocial'nyj potencial v svete istoriko-geografičeskih dannyh konca XVIII veka", CARELiCA 1 (2013): 20-21, accessed 21.05.2016, http://carelica.petrsu.ru/2013/Chernyakova_1.pdf.

${ }^{28}$ See for details: Tikkanen et al., Past human population; Tikkanen et al., Vanished villages. thatveely dominated in the Vodlozero area landscape 1. Vanished villages.
} 
geographic landscape. Our analysis of habitats, formed by groups of settlements, is dictated by the fact that communal agricultural lands (allmende), which definitely included surrounding forests, have always been used collectively by communities of village, volost or parish (until 1917) and rural council after 1917.

The time frame of current study is determined by an ambition to catch the initial impulses of future depopulation and the availability of data sources which can be compared reliably. The upper margin of the period is set in 1930s, since we have available an exhaustively complete list of settlements in the region, compiled based on the pre-war census materials - Spisok 1933. This source is slightly limited for our purpose as it only contains information about male and female population recorded in each village. Earlier publications of this kind are more informative as they also contain data about the households, which are very useful for our specific objectives - Spisok 1905 and Spisok 1926. Close to the informative content of these sources is the earliest list of settlements of $1873^{29}$ (hereinafter Spisok 1873). We are forced to acknowledge that systematic information about livestock is at present only available from Spisok 1905. The lower margin of the time frame is set based on the available documents that were compiled during the last decade of the $18^{\text {th }}$ century. The General Land Survey of Olonets Gubernia (Generalnoe Mezhevanie Olonetskoi Gubernii, hereinafter GMOG) was developed in Pudozh county (uyezd) in 1791, which also included the Vodlozero area. These materials are now available digitally through the electronic cartographical information system. ${ }^{30}$ The so-called General Land Survey Plans ${ }^{31}$ (Plany Generalnogo Mezhevaniya, hereinafter PGM), which are included in $G M O G$, also play a critical role in our research. These plans actually constitute the earliest documented landscape-oriented semi-instrumental land survey with a predetermined scale (see Figure 2). Another source never before applied to a Vodlozero-related study is the economic annotation: short (Kratkie Ekonomicheskie Opisaniya, hereinafter $\mathrm{KEO})^{32}$ and cameral (Ekonomicheskie Kameralnye Primechaniya, hereinafter $E K P) .{ }^{33}$ GMOG compilers matched quantitative and narrative information contained in the annotations with the $P G M \mathrm{~s}$, which allows us to tie and visualise identified facts and processes of regional development to a specific territory and landscape.

\footnotetext{
${ }^{29}$ Evlampij Ogorodnikov, ed., Spiski naselennyh mest Rossijskoj imperii po svedeniâm 1873 goda: Oloneckâ̂ guberniâ, 180-181.

${ }^{30}$ Irina Černâkova et al., General'noe meževanie Oloneckoj gubernii: Kartografičeskâ̂ spravočno-informacionnaâ Sistema, accessed 21.05.2016, http://maps.karelia.ru/mez.

${ }^{31}$ Plany General'nogo Meževaniâ Pudožskogo uezda Oloneckoj gubernii, Rossijskij gosudarstvennyj arhiv drevnih aktov (further RGADA), F. 1356. D. 3352-3361.

${ }^{32}$ Kratkie èkonomičeskie opisaniâ $k$ kartam General'nogo meževaniâ Oloneckojgubernii: Pudožskij uezd, 1791 g. (further KEO), RGADA, F. 1355. D. 921. L. 1-14.

${ }^{33}$ Èkonomičeskie kameral'nye primečaniâ k kartam General'nogo Meževaniâ Oloneckoj gubernii: Pudožskij uezd, 1791 g. (further EKP), RGADA, F. 1355. D. 922. L. 1-44.
} 
Figure 2. The Vodlozero area on the map of GMOG 1791 (the raster image)

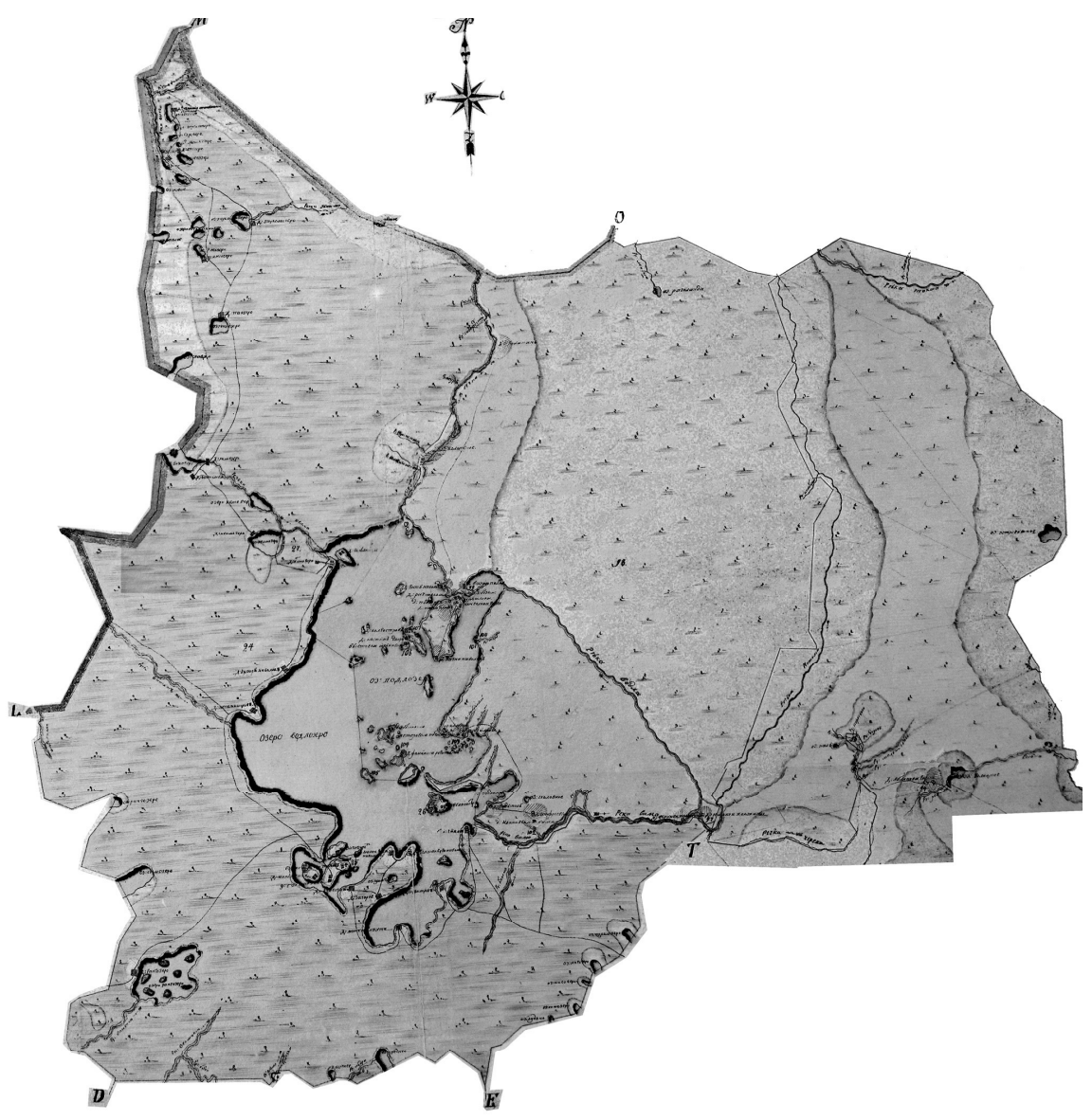

Source: Plany General'nogo Meževaniâ Pudožskogo uezda Oloneckoj gubernii, Rossijskij gosudarstvennyj arhiv drevnih aktov (further RGADA), F. 1356. D. 3352-3361.

\section{Methodology}

Verifiability and comparability of quantitative information are important requirements in any historical and demographical study. The validity of socially significant computations is increasingly important when studying processes and events stretched across centuries and geographical locations. It is a known fact 
that the administrative structure of the region was subject to numerous reforms, which in turn led to shifts in the territorial boundaries of local village communities. Therefore, analyzing a number of quite widely known and available documents, which contain quantitative information regarding regional development, implies a thorough tracing of numerical data for each village within all administration units - i.e., church parishes (pogost), districts (volost) as local communities, which were replaced by rural councils (selski sovet, or in its shortened form sel'sovet) during Soviet times.

The information available about each village is extremely important, particularly in the part based on interviews with local inhabitants. At first glance, the statistical calculations of Loginov look exhaustive and thorough. ${ }^{34}$ However, in an attempt to further consolidate this data certain gaps were revealed. Adressing the original data source confirmed these discrepancies. Therefore, all calculations in the present article are based on primary data sources, including previously published lists of settlements in Olonets province of 1873, 1905, 1926 and 1933, as well as materials of the General Land Survey (1791), hereby introduced for the first time.

It is not sufficient to rely solely on total figures, and thus the quantative data presented in this article has been disaggregated into all settlements of the region. We consider the administrative devision to be a nominal structure, useful for governmental purposes, but not definitively important for the tradition of local land use and demographic behaviour.

In our retrospective study of the social and demographic potential of Vodlozerie, it is no less important for us to also take into consideration the landscape background of the administrative and governmental decisions. Without this, it is not possible to adequately trace the historic reality that has sunk into oblivion.

\section{The region and the ups and downs of its territorial-administrative organisation}

According to the earliest of our sources - GMOG - there were registered 47 villages in the vast Vodlozero territory: 26 of these, including one newly established, were grouped within Prechistenski pogost (Kuganavolok area), and 21 villages constituted Vodlozero volost (Kanzanavolok area). In the succeeding source - Spisok 1873 - we find 42 settlements in Vodlozerie collectively listed as located "near the lake of Vodlozero, on its islands and nearby lakes". ${ }^{35}$ It should be

\footnotetext{
${ }^{34}$ Loginov, Istoričeskaâ spravka.

${ }^{35}$ Spisok 1873, 180-181.
} 
noted that two more villages, Ragnozero and Goliyanitsi, traditionally considered as part of Vodlozerie, are localised differently: among settlements located "on the country road from Pudozh to Povenetz, on the right side", and among settlements located ,along Vodla river, upstream from the town of Pudozh". ${ }^{36}$ The same is true of the group of villages which we hereinafter refer to as Yangozero villages. Their exclusion from the Vodlozero settlements list seems absolutely logical when one looks at the map of the area. Since the Spisok 1873 does not contain any division by parish or district, its compilers focused solely on the infrastructure as dictated by the local landscape, where settlements are listed following the order of their placement along the roads, shores or islands. Indeed the villages of Paezero, Yangozero, Kukamos, Egozero, Uzkozero/Uskoie and Svetlozero/Zamoshie do not gravitate to the lake of Vodlozero, as they are located significantly further to the northwest of it. They can be „found" as part of Povenets county, located "along the country road from Povenets to Pudozh, on the eastern shore of the lake Onego". ${ }^{37}$ Nevertheless, in the beginning of the $20^{\text {th }}$ century, Yangozero villages were again included in Vodlozerie and became an integral part of the knewly established Pilmasozero community. ${ }^{38}$

As it turned out, the naming of village councils established in the region during Soviet rule, with those rural societies which were prior to them did not fully match. For example, three villages that were earlier part of Kanzanavolok community appeared to be included into Kuganavolok rural council: Bykovskaia, Okhtom-ostrov, Pelgostrov. ${ }^{39}$ Five villages, which previously belonged to Pilmasozero community (Egozero, Kukamos-ozero, Svetlozero/Zamoshie, Uskoye/Uzkozero, Yangozero), were taken out of the list of Vodlozero settlements altogether and added to Kudozero rural council, in Povenets, which later became Medvezhiegorsk, district (raion), instead. ${ }^{40}$ At the same time the sixth of the Yangozero villages, Paezero, remained within Vodlozerie. ${ }^{41}$ Luza village area only appears included in Vodlozerie once - in the Spisok $1905 .{ }^{42}$ One may consider that the settlement of Luza became part of the Vodlozero area (Pudozh county of Olonets gubernia) in $1903,{ }^{43}$ but it is clear that this happened much earlier -in

\footnotetext{
${ }^{36}$ Spisok 1873, 182.

${ }^{37}$ Spisok 1873, 165-166.

${ }^{38}$ Spisok 1905, 250-251.

${ }^{39}$ Spisok 1905, 248-249; Spisok 1926, 103-104.

${ }^{40}$ Spisok 1905, 250-251; Spisok 1926, 39-40; Spisok 1933, 26-27.

${ }^{41}$ Spisok 1926, 102; Spisok 1933, 76.

${ }^{42}$ Spisok 1905, 250-251.

${ }^{43}$ Konstantin Loginov, K probleme ètnokul'turnogo razvitiâ Srednego Poileks'â i Severnogo Priileks'â, accessed 21.05.2016, http://folk.pomorsu.ru/index.php?page=opensource/27.
} 
$1891 .{ }^{44}$ In accordance with the list of 1926 , this village was no longer part of Vodlozerie, but became one of the settlements of the rural council of Nosovo (Onega district of Archangelsk province). ${ }^{45}$

One cannot say that pre-revolutionary governmental practice was not familiar with such formal transfer of settlements from one administrative jurisdiction to another. It did happen in this area, although never on a particularly significant scale. Thus, according to the data of 1905, Gumarnavolok and Okhtom-ostrov were transferred from the Kuganavolok part of the region to the Kanzanavolok part, ${ }^{46}$ while Vavdipole, Vama, Anufrievskaia, Borovoi Porog and Vamski Porog, which once was a field plot in use for special tax (obrochnaya pustosh), which according to GMOG 1791 belonged to the Kanzanavolok part, ended up as part of the Kuganavolok community. ${ }^{47}$ The same thing happened to other groups of villages.

The general settlement structure of the region had been rather stable. ${ }^{48}$ It is the administrative division of the Spisok 1905 that we take as a basis for our study as being the most established and traditional, not yet disturbed by the events of the near future.$^{49}$ According to this list, there were 48 villages in Vodlozero volost, divided into three communities (later rural councils): Kanzanavolok (19 settlements), Kuganavolok (18) and Pilmasozero (11). ${ }^{50}$ In the second half of the 1920s, there was established a fourth rural council, which was centered around Chuyala and included eight villages from the former Kuganavolok community: Vavdipole, Vama, Anufrievskaya, Velikostrov, Kuseostrov and two more with two long descriptive names: O Vamu reku o Borovoi porog and O Vodlu reku o Vamski porog

${ }^{44}$ Rossijskâ̂ imperiâ. Administrativno-territorial'noe delenie:1708-1917. Oloneckaâ guberniâ, 1775-1897 gg., accessed 21.05.2016, http://www.nlr.ru/res/refer/r_imp/gub/olon.html.

${ }^{45}$ Spisok 1926, 102-104; Administrativno-territorial'noe delenie Onežskogo rajona, accessed 21.05.2016, http://www.onegaonline.ru/html/dz2/seetext.asp?kod=540.

${ }^{46}$ Spisok 1905, 248.

${ }^{47}$ EKP 1791, reverse side of the sheet 12 (hereinafter oborot, in short form 12ob), 28ob-31.

${ }^{48}$ See complete full table of compliance, administrative conditioning of settlements of the Vodlozero area during the period from 1791 to 1933 in: Černâkova, Vodlozer'e - poselenčeskie landšafty, 24-25: table 1.

${ }^{49}$ It should be emphasized that Spisok 1926 and Spisok 1933 are both compiled in alphabetical order. The settlements are listed within their administrative and territorial units: rural councils, without any reference to landscape or road infrastructure and even without mention of lakes or rivers on the banks of which they were located. In Spisok 1905 settlements are also grouped by village communities (volost); however, inside the order is traditionally territorial. It should be noted that in Russian state paperwork the custom was to show settlements as linked to the landscape as if following a road from one to another. The compilers of Spisok 1873 coordinated information about settlements' localization precisely in this way. As early as the $16^{\text {th }}-17^{\text {th }}$ centuries it was done in the same way by the scribes, whose task was to compile cadastral documents of mass character - scribe and census books.

${ }^{50}$ Spisok 1905, 248-251. 
(hereinafter shortened versions of their names will be used: Borovoi Porog and Vamski Porog). ${ }^{51}$ The first two included also two church parish-places (pogost): of St. Elijah (hereinafter - Ilyinski) and of the Blessed Virgin Mary (hereinafter - Prechistenski), which strictly speaking were not villages. Both were inhabited by clergy and their families living by the church: 15 people in two houses and 10 people in three houses, respectively. Even though our source counts them as non-peasant population, the pogosts inhabitants also took part in agricultural work. Traditionally, since the days of scribe books' composition, churches were entitled to ownership of both arable land and hayfields. As a side note, based on the information from 1926, both pogosts contained three households and 17 people each, and two of the households of the Prechistenski pogost were inhabited by non-peasants. ${ }^{52}$ Seven years later, five people were registered at the church of Ilyinski, and eight people at Prechistenski pogost. ${ }^{53}$

\section{Habitability of the region and main sources of inhabitants' sustenance}

As mentioned earlier, the economic activity, carried out for centuries in numerous villages located on the bays and islands of Vodlozero lake, on the shores of inflowing rivers Kelka and Ileksa (northwestern coast) and outflowing Vama (southeastern coast), as well as many small lakes, creeks and rivulets, fell into decay to the second half of the $20^{\text {th }}$ century.

It should be emphasized that previously the local population had always managed to overcome the aftermath of wartime devastation and bad harvests, and had coped with the tax burden despite the objectively low productivity of agriculture in this circumpolar area, aggravated by the dramatic circumstances of various political cataclysms. Based on the quantative records of regional development (number of households and their inhabitants) identified and comparatively analysed in this article, the region of Vodlozerie had shown a steady growth in demographic potential in the period from the last decade of the $18^{\text {th }}$ century until the first third of the $20^{\text {th }}$ century. However, one cannot fail to notice that already in the beginning of the 1930s all village councils without exception had experienced not just stagnation but evident decrease in number of inhabitants (see Table 1).

${ }^{51}$ Spisok 1926, 248-249; Spisok 1933, 77. For detailed explanation of the existing confusion in the administrative affiliation and interpretation of the naming of these two settlements in the documentary sources and in the historiography, see: Černâkova, Vodlozer'e - poselenčeskie landšafty, 26: note 5 .

${ }^{52}$ Spisok 1926, 103-104.

${ }^{53}$ Spisok 1933, 76-77. 
Table 1. Distribution of population in Vodlozerie in the end of the $18^{\text {th }}$ century the first third of the $20^{\text {th }}$ century

\begin{tabular}{|c|c|c|c|c|c|c|c|c|c|}
\hline \multirow{2}{*}{$\begin{array}{l}\text { Community centre } \\
\text { (pogost, volost, sel- } \\
\text { skoe obshchestvo, } \\
\text { selski sovet) }\end{array}$} & \multicolumn{2}{|c|}{1791} & \multicolumn{2}{|c|}{1873} & \multicolumn{2}{|c|}{1905} & \multicolumn{2}{|c|}{1926} & \multirow{2}{*}{ 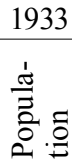 } \\
\hline & 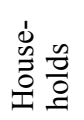 & 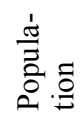 & 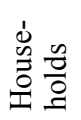 & 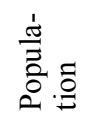 & 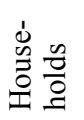 & 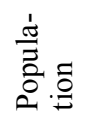 & 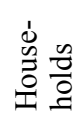 & 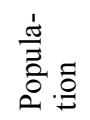 & \\
\hline Kanzanavolok & 129 & 973 & - & $\bullet$ & 232 & 1332 & 255 & 1215 & 1145 \\
\hline Kuganavolok & 153 & 1176 & • & • & 185 & 1084 & 307 & 1378 & 892 \\
\hline Pilmasozero & • & • & $\bullet$ & • & $112^{\mathrm{a}}$ & $636^{\mathrm{a}}$ & $168^{b}$ & $894^{\mathrm{b}}$ & $835^{\mathrm{b}}$ \\
\hline Chuyala & $\bullet$ & • & • & $\bullet$ & • & $\bullet$ & $\bullet$ & • & 418 \\
\hline Total & 282 & 2149 & 404 & 2598 & 529 & 3052 & 730 & 3487 & 3290 \\
\hline $\begin{array}{l}\text { Average } \\
\text { per household }\end{array}$ & \multicolumn{2}{|c|}{7.62} & \multicolumn{2}{|c|}{6.43} & \multicolumn{2}{|c|}{5.77} & \multicolumn{2}{|c|}{4.78} & - \\
\hline
\end{tabular}

${ }^{\mathrm{a}}$ Excluding Luza village; ${ }^{\mathrm{b}}$ Including Yangozero area villages.

Source: KEO, 4, 8-8ob; Spisok 1873, 165-166, 180-181; Spisok 1905, 248-251; Spisok 1926, 3940, 102-104; Spisok 1933, 76-77.

An important component of the social pattern of Vodlozerie at the end of the $18^{\text {th }}$ century, which we are interested in, is the average density of population in different parts of the region. Table 2 below shows that in accordance with GMOG, the population concentrated on the shores of Lake Vodlozero itself was spread only slightly unevenly: 973 people lived in 21 villages of the northeastern part (Kanzanavolok), named in the source as Vodlozero volost; while the southwestern part (Kuganavolok), defined in the source as Vodlozero pogost, was inhabited by 999 people. However, when adding to the latter the six Yangozero villages, included in this part by GMOG although located further to the northwest from the lake Vodlozero, we get a total number of inhabitants of the Kuganavolok part and separate village Ilyina Gora: 1176 people. When calculating the average density of population, we cannot avoid this, as available land was defined for all 26 settlements of Vodlozero Prechistenski parish together (dachas 24 and 2754). A1together in 1791 there lived 2149 people in Vodlozerie region.

${ }^{54}$ Dacha - territorial administrative unit of the State land fund, attributed by GMOG to separate owners. These could be private persons, for example landowners, or corporate owners, for example townspeople, but more often they were inhabitants of the villages or groups of villages. There does not seem to be any particular order of the dacha's structure in the documentary source. They could be both exceptionally large in size and very small; they could belong to whole village community or to a separate village. Presumably, the system of dacha as land allotment reflected traditional land use, registered by State in the end of the $18^{\text {th }}$ century. It was spontaneously formed and established in ancient times, at least for local peasants, based originally on capture law. Obviously the process can be understood by taking into account land use as it was recorded in the scribe books of the first third of $17^{\text {th }}$ century. It is no coincidence that church's dacha, which were never subject to re-divisions, are called cadastral land (pistsovaya zemlya) in GMOG. 
Table 2. Population of villages in Vodlozerie according to GMOG of 1791

\begin{tabular}{|c|c|c|c|c|c|c|}
\hline \multirow[b]{2}{*}{ Dacha } & \multirow[b]{2}{*}{ Settlements ${ }^{\mathrm{a}}$} & \multirow{2}{*}{$\begin{array}{l}\text { House } \\
\text { holds }\end{array}$} & \multicolumn{3}{|c|}{ Number of inhabitants } & \multirow{2}{*}{$\begin{array}{c}\text { Average } \\
\text { per } \\
\text { household }\end{array}$} \\
\hline & & & men & women & total & \\
\hline \multirow{26}{*}{24} & Kevasalma & 6 & 30 & 33 & 63 & 10.5 \\
\hline & Bolshoi Kuganavolok & 9 & 32 & 28 & 60 & 6.7 \\
\hline & Malyi Kuganavolok & 13 & 62 & 52 & 114 & 8.8 \\
\hline & Velikostrov & 6 & 15 & 20 & 35 & 5.8 \\
\hline & Chuyala & 8 & 30 & 23 & 53 & 6.6 \\
\hline & Kuzeostrov & 4 & 11 & 19 & 30 & 7.5 \\
\hline & Matkalakhta & 4 & 15 & 15 & 30 & 7.5 \\
\hline & Bostilova & 11 & 48 & 45 & 93 & 8.5 \\
\hline & Ragnozero & 9 & 22 & 26 & 48 & 5.3 \\
\hline & Malaya Poga & 7 & 30 & 41 & 71 & 10.1 \\
\hline & Bolshaya Poga & 4 & 30 & 44 & 74 & 18.5 \\
\hline & Vygostrov & 5 & 31 & 29 & 60 & 12.0 \\
\hline & Okhtomostrov & 9 & 30 & 31 & 61 & 6.8 \\
\hline & Gumarnavolok & 7 & 49 & 29 & 78 & 11.1 \\
\hline & Goliyanitsy & 2 & 5 & 5 & 10 & 5.0 \\
\hline & Pustinya & 4 & 18 & 17 & 35 & 8.8 \\
\hline & Zagorie & 5 & 16 & 19 & 35 & 7.0 \\
\hline & Pilmas-ozero & 7 & 26 & 23 & 49 & 7.0 \\
\hline & Ukshezero & 2 & 12 & 7 & 19 & 9.5 \\
\hline & Paezero & 2 & 8 & 3 & 11 & 5.5 \\
\hline & Zamoshie (Svetloie) & 5 & 13 & 13 & 26 & 5.2 \\
\hline & Egozero & 4 & 9 & 7 & 16 & 4.0 \\
\hline & Uskoya & 1 & 4 & 3 & 7 & 7.0 \\
\hline & Kukamus-ozero & 3 & 13 & 6 & 19 & 6.3 \\
\hline & Yangozero & 6 & 13 & 8 & 21 & 3.5 \\
\hline & Total & 143 & 572 & 546 & 1118 & 7.8 \\
\hline 27 & Ilyina Gora & 10 & 30 & 28 & 58 & 5.8 \\
\hline \multirow{22}{*}{98} & Vama Ivanovskaya & 8 & 43 & 38 & 81 & 10.1 \\
\hline & Anufreevskaya & 6 & 14 & 10 & 24 & 4.0 \\
\hline & Borovoi Nizhnei poloviny (Porog) & 2 & 7 & 2 & 9 & 4.5 \\
\hline & Vavdipole & 3 & 11 & 15 & 26 & 8.7 \\
\hline & Putilova & 10 & 38 & 32 & 70 & 7.0 \\
\hline & Putilova na gore & 2 & 14 & 8 & 22 & 11.0 \\
\hline & Ragunova (Fominskaya) & 8 & 28 & 25 & 53 & 6.6 \\
\hline & Nesterovskaya (Pelgostrov) & 6 & 26 & 26 & 52 & 8.7 \\
\hline & Navolok (Bykovskaya) & 3 & 20 & 17 & 37 & 12.3 \\
\hline & Kanzanavolok & 18 & 59 & 59 & 118 & 6.6 \\
\hline & Kolgostrov & 13 & 50 & 49 & 99 & 7.6 \\
\hline & Kostin Dvor & 6 & 19 & 18 & 37 & 6.2 \\
\hline & Mikhailovskaya Verkhnei poloviny & 1 & 11 & 4 & 15 & 15.0 \\
\hline & Itom Gora (Kaskosalma) & 5 & 23 & 17 & 40 & 8.0 \\
\hline & Angilova Gora & 10 & 37 & 36 & 73 & 7.3 \\
\hline & Kurgalova & 4 & 14 & 15 & 29 & 7.3 \\
\hline & Podgorie & 7 & 26 & 26 & 52 & 7.4 \\
\hline & Rakhkolova & 5 & 23 & 18 & 41 & 8.2 \\
\hline & Varishpelda & 7 & 26 & 31 & 57 & 8.1 \\
\hline & Gostnavolok & 3 & 16 & 9 & 25 & 8.3 \\
\hline & Kalakun Porog & 2 & 4 & 9 & 13 & 6.5 \\
\hline & Total & 129 & 509 & 464 & 973 & 7.5 \\
\hline \multicolumn{2}{|c|}{ Grand tot } & 282 & 1111 & 1038 & 2149 & 7.6 \\
\hline
\end{tabular}

a Spelling of the names of villages as it is in the documentary source.

Source: EKP, 12ob, $28 \mathrm{ob}-31$. 
The number of households in a village as well as average household size had never been particularly large. However, according to the historical sources that we have analised, there had been a few large villages with a population above 100 people. At the end of the $18^{\text {th }}$ century these were Kanzanavolok, inhabited by 118 people in 18 households, and Malyi Kuganavolok (114 people in 13 households). The population of Kolgostrov was approaching the same level (99 people in 13 households).

The average household population appear to be the same in both parts of Vodlozerie in the end of the $18^{\text {th }}$ century: 7.8 in the southwestern area of Kuganavolok and 7.5 in the northeastern area of Kanzanavolok. At the same time some settlements were examples of an exceptionally large size of household dwelling. These were Bolshaya Poga, located on the same island as the ancient Prechistenski pogost, with 18.5; Mikhailovskaya/Vachalova, located on an island near to Ilyinski island, with 15; and the island village Vygostrov in the southern part of the Lake Vodlozero with 12 people per household. Bykovskaya village occupying the northern cape of Pelgostrov island (see Figure 1) had the same average population per household.

A century later, in 1873, Kanzanavolok was still the largest village with 145 people in 24 households, Kolgostrov came second (122 people in 15 households) and Ragnozero was a close third (121 people in 16 households). Putilovo (98 in 18) and Chuyala (97 in 16) were both approaching the 100-people mark. Yet we do not find as densely inhabited households in Vodlozerie as a hundred years before. According to the data from 1873, the average household size in the region was 6.4 persons. The highest average number -7.5 persons - was recorded in Kolgostrov and Ragnozero; while between 5.5 and 6.5 persons per household lived in Kanzanavolok, Putilova, Goliyanitsi and Borovoi Porog. ${ }^{55}$

As shown in table 1 above, in the first quarter of the $20^{\text {th }}$ century the average household population continued to decrease, reaching 5.77 and 4.78 in 1905 and 1926, respectively. Not that this curve of demographic development should be seen as an evidence of any kind of decay or stagnation. On the contrary, there is every reason to believe that positive development trends can clearly be detected a decade into the Soviet rule. Despite the recent cataclysms of the Soviet government establishment and the Civil War, which had not bypassed Vodlozerie, the discovered quantative data is convincing of the tendency to prosperity. As shown in Figure 3, the number of homesteads was constantly raising.

\footnotetext{
${ }^{55}$ Spisok 1873, 180-182.
} 
Figure 3. The number of households and population in the Vodlozero area from the late $18^{\text {th }}$ untill the first third of the $20^{\text {th }}$ century

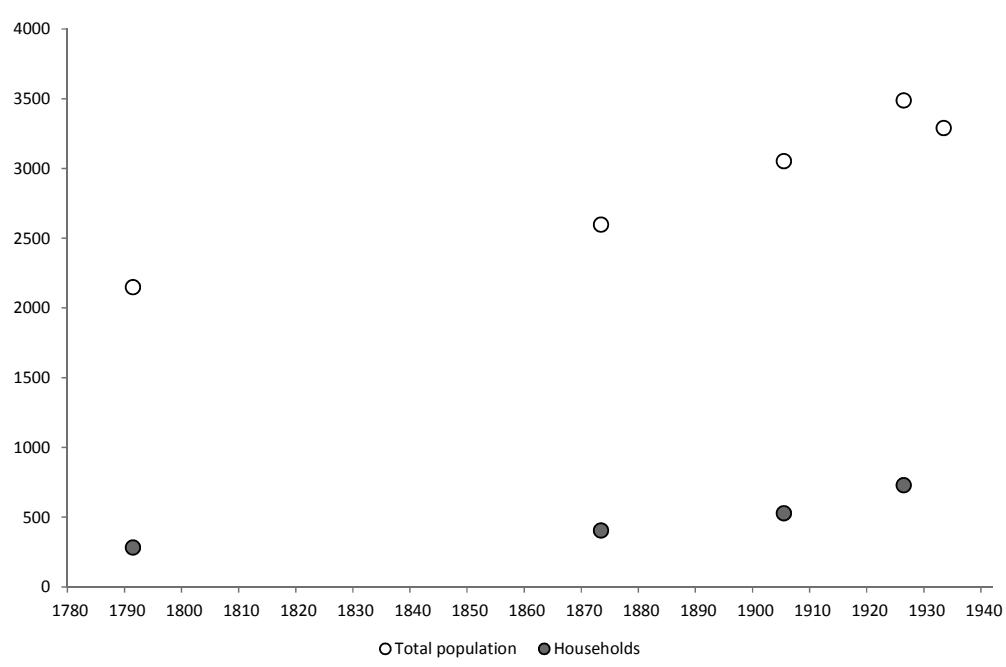

Source: KEO, 4, 8-8ob; Spisok 1873, 165-166, 180-181; Spisok 1905, 248-251; Spisok 1926, 3940, 102-104; Spisok 1933, 76-77.

According to the data recorded in 1926, Kanzanavolok, the largest village of the region, was then inhabited by 216 people, while the number of households had doubled since 1873 to almost fifty (49). The number of households in Kolgostrov had almost tripled (from 13 to 33), while the population had increased by one third and reached 149. Ragnozero had also noticeably grown (from 16 to 33 households) with a simultaneous increase in total population of the village by one third (from 121 to 179 people). More than 100 people inhabited some other villages, such as Gumarnavolok (154), Putilova (105) and Okhtom-ostrov (103). ${ }^{56}$ Yangozero villages, which by 1926 were no longer part of Vodlozero administrative and territorial units, but were instead added to Kodozero rural council of Povenetz (after 1933, Medvezhiegorsk) region, remained significantly less populated. Nevertherless, they are included in the total figures in our research in order to ensure full comparability with the earlier quantitative data. Altogether, according to Spisok 1926, the five villages Egozero, Kukamosozero, Svetlozero, Uzkozero ${ }^{57}$ and Yangozero were inhabited by 236 people occupying 38 households. ${ }^{58}$

\footnotetext{
${ }^{56}$ Spisok 1926, 102-104.

${ }^{57}$ Spisok 1926, 40. The source in error spells the name as Ukshezero, whereas it should be Uzkozero (derived from previously recorded Uskoya (see: GMOG) and Uzkozero (see: Spisok 1783).

${ }^{58}$ Spisok 1926, 39-40.
} 
Besides the clergy, agriculture was not the exclusive means of sustenance for only a very few residents of the region. In the begining of the $20^{\text {th }}$ century there were only ten such families in four villages: Kanzanavolok (17 persons), Mikhailovskaia/Vachilova (6), Kuganavolok (13) and Velikostrov (3).$^{59}$ In this sense Vodlozerie represented a socially homogenious territory, not any different from the rest of Pudozh region. According to the First General Population Census of Russian Empire (1897), 95\% of the inhabitants of this county were peasants. ${ }^{60}$

The inhabitants managed to secure subsistence and reproduction by virtue of well developed arable farming and trade. Cattle breeding played a supporting role and was mostly used to help the fertility of the land surrounding the villages, as it was of a rather poor quality and needed regular manuring.

According to the records made at the very beginning of the $20^{\text {th }}$ century, in the Vodlozero area a total of 2757 cattle were registered. Evidently, one household kept on average not even a single horse, a little more than one cow and less than two sheep (see Table 3).

Table 3. Number of cattle kept by the inhabitants of Vodlozerie at the beginning of the $20^{\text {th }}$ century

\begin{tabular}{lccccrrcc}
\hline \multirow{2}{*}{$\begin{array}{c}\text { Village commu- } \\
\text { nity }\end{array}$} & $\begin{array}{c}\text { Number } \\
\text { of house- } \\
\text { holds }\end{array}$ & horses & cows & other & total & $\%$ & $\begin{array}{c}\text { Average } \\
\text { per } \\
\text { household }\end{array}$ \\
\hline Kanzanavolok & 232 & 192 & 260 & 376 & 1060 & 38.4 & 4.6 \\
Kuganavolok & 185 & 175 & 232 & 336 & 928 & 33.7 & 5.0 \\
Pilmasozero & 154 & 139 & 215 & 261 & 769 & 27.9 & 5.0 \\
Grand total & 571 & 506 & 707 & 973 & 2757 & 100.0 & 4.8 \\
\hline
\end{tabular}

Source: Spisok 1905, 248-251.

According to Table 3, there was evidently more livestock in the northern part of Vodlozerie, including Kanzanavolok and Pilmasozero areas together (ca. 66\%) than in the southern part of Kuganavolok. „Pudozh inhabitants, bound to their wild forests, support themselves with fishing, husbandry, and cattle breeding", Nikolai Kharuzin testified. He was a well-known $19^{\text {th }}$-century ethnographer, who visited the Lake Vodlozero neighborhood in 1878 together with his sister Vera Kharuzina, a keen observer and a great portrayer of folk customs and people's everyday life. „The significance of the two first types of activities varies from area to area”, he

\footnotetext{
${ }^{59}$ Spisok 1905, 248-251.

${ }^{60}$ Nikolaj Trojnickij, ed., Pervâ̂ vseobŝâ̂ perepis' naseleniâ Rossijskoj imperii 1897 g.: Oloneckaâ guberniâ (Moskva 1899), 34-35.
} 
continues. "In some places peasants see fishing as their primary occupation, and husbandry plays a secondary role for them, while in other places husbandry, by contrast, is the main source of living, with fishing playing a subsidiary [supporti$v e-\mathrm{I}$. Ch.] role. What always is carried out in parallel is arable farming and cattle breeding. Where husbandry is more developed, there is also well-developed livestock breeding. This makes so much sense: Pudozh soil is so poor that even when well manured it cannot feed a peasant for a whole year, and without fertilizing you can hardly grow anything at all. This infertility of the soil explains the necessity of keeping more cattle to be able to manure the soil somehow. Infertility also makes it necessary to resort to slash-and-burn farming and use so-called lyadinas, which... provide them with enough bread for the whole year". ${ }^{61}$

Indeed it looks as if the crucial role was played by traditional cultivation of cereals and root crops, not so much in the regular fields near the villages, but rather in the forest fields, so called slash plots (podseka). The tremendously hard work required to prepare this kind of field for seeding was quite usual for local peasants, as persuasively described in the notes of the ethnographer Vera Kharuzina.$^{62}$ As she testified, "... people inhabiting the banks of big Vodlozero... are mainly engaged in fishing”, and added, “... they had been doing arable farming to begin with, but were forced to switch to fishing after governmental prohibition of the slash-and-burn method". ${ }^{63}$ However, the slash-and-burn farming continued to be practiced by local communities in spite of the prohibition until the middle of the $20^{\text {th }}$ century. Local people have recalled that Vodlozerie inhabitants did not starve to death during the Great Patriotic War only because they grew turnips on the slash-and-burn plots in the forests. Some people in Vodlozerie still explain that it was only possible because of "a smart head of the local collective farm (kolkhoz)" who knew about it, but chose not to inform local authorities. ${ }^{64}$

\section{Traditional land tenure in Vodlozerie}

Distribution of land between the settlements and their inhabitants, recorded during the surveying in 1791, is a kind of key to understanding the system of traditional land use in the region. The settlements are clearly localised in $P G M$ into several clusters to the northwest, northeast, southeast and south of Lake Vodlozero (see Figure 4). Descriptions (KEO and $E K P$ ) in accordance with system

${ }^{61}$ Nikolaj Haruzin, "Iz materialov, sobrannyh sredi krest'ân Pudožskogo uezda", Oloneckij Sbornik 3 (1894): 306-307.

${ }^{62}$ See for details: Vera Haruzina, Na Severe: putevye vospominaniâ (Moskva 1890), 29-31.

${ }^{63}$ Haruzina, Na Severe, 56.

${ }^{64}$ Loginov, Istoričeskaâ spravka. 
Figure 4. The Vodlozero area on the map of GMOG 1791 (the digitized image)



Source: as in Figure 2.

of dacha include all agricultural areas used by inhabitants which were mapped strictly according to their places on the lakes, rivers and streams. The compiler of EKP added in regards to dacha 24: "The soil is oozy and more suitable for growing rye and oats than any other crops. Hayfields are also of a rather mediocre quality. Forest is suitable for construction: pine and spruce - from 6 to 9 vershok $^{65}$ [26-40 centimeters] in diameter and from 7 to 11 sazhen $^{66}$ [15-24 meters] tall; and firewood: aspen, birch, pine, spruce, willow and bird-cherry". ${ }^{67}$ To show the

\footnotetext{
${ }^{65}$ Vershok, an old Russian measure of length (until 1924), equals $4.45 \mathrm{~cm}$.

${ }^{66}$ Sazhen, an old Russian measure of length (until 1924), equals 2.14 m; one sazhen equals 48 vershok.

${ }^{67}$ EKP, 13.
} 
similarity in the charactistics of different agricultural areas in Vodlozerie by two sources - the EKP and $K E O$ - there is the citation of a brief description of dacha 98: „The soil is oozy and stony. Crop and grass harvests are mediocre. Forests are suitable for construction and as firewood". ${ }^{68}$

The extended description adds some information to the one cited above: "The soil is oozy and full of stones. Crop harvest is mediocre if soil is not fertilised. Hayfields are good in some places, and bad in others. Ploughfields are not abundant. However, there are many forests providing constructional timber: spruce and pine, 7 to 9 vershok in diameter, 10 or more sazhen tall, but not suitable for ship-building; different kinds of firewood; and hunting grounds for wild animals: bears, wolves and hares, as well as birds: grouse, partridge, and when close to water, swans and wild ducks". In passing the compiler notes: "the main occupation of local peasants is arable farming", and clarifies right thereafter: "some of them set out to Saint Petersburg and find jobs there; women, besides working in the fields, spin flax and wool, and weave linen and cloth for their families". ${ }^{69}$

In the light of our research goals, environmental conditions of the agricultural activities performed by Vodlozerie inhabitants, which are described in the materials of $G M O G$, are the most valuable information. Compilers have measured the whole area in desyatina and sazhen, including the territories occupied by the settlements, ploughed village fields, hayfields, forests and so-called wasteland not suitable for any kind of practical use (neudobiya). After re-calculating the documented measurements in modern day hectares, we can conclude that forests took up $90.4 \%$ of the whole territory in the region, $8.7 \%$ was wasteland, and only $0.9 \%$ of the area was allocated to the settlements themselves including all regular ploughfields and hayfields (see Table 4).

So during GMOG the territory of Vodlozero was split into 15 dachas, geographically rather clearly comprising two zones: 24-27 and 97-107. At the same time all known settlements in Vodlozerie were attributed to just two of the 15 dachas: 24 and 98. Dacha 27 was a state owned wasteland, reserved during GMOG for a newly settled village, most likely later known as Golia Gora (called Ilyina Gora in GMOG materials - I. Ch.). All the other dachas were either abandoned fields on servage (obrochnaya pustosh) $(26,105)$, or state-owned land (kazennaya zemlya) $(99,100,102,103,104,107)$, or state-owned hayfields $(97,101)$ belonging to different villages. Two of dachas are recorded in GMOG materials as the land of Prechistenski (25) and Ilyinski (106) pogosts.

In the whole of Vodlozerie, according to our calculations, the amount of land with various purposes made up 375,503 hectars at the end of the $18^{\text {th }}$ century.

\footnotetext{
${ }^{68} \mathrm{KEO}, 8$.

${ }^{69}$ EKP, 29.
} 
Table 4. Land distribution in Vodlozerie according to GMOG of 1791 (in hectars)

\begin{tabular}{|c|c|c|c|c|c|c|c|}
\hline \multirow[b]{2}{*}{ Dacha } & \multirow[b]{2}{*}{$\begin{array}{c}\text { Dacha's } \\
\text { composition }\end{array}$} & \multicolumn{6}{|c|}{ Land area and it's purpose } \\
\hline & & $\begin{array}{l}\text { Home- } \\
\text { steads }\end{array}$ & $\begin{array}{l}\text { Ploughed } \\
\text { fields }\end{array}$ & Hayfields & Forest & $\begin{array}{l}\text { Waste- } \\
\text { land }\end{array}$ & Total \\
\hline 24 & $\begin{array}{l}\text { Kuganavolok } \\
\text { with villages }^{\text {a }}\end{array}$ & 104 & 1505 & 528 & 222535 & 12013 & 236685 \\
\hline In perce & ntage & 0.04 & 0.64 & 0.22 & 94.02 & 5.08 & 100,00 \\
\hline 25,26 & $\begin{array}{l}\text { Prechistenski } \\
\text { pogost }\end{array}$ & 2 & 103 & 1 & 9 & 102 & 217 \\
\hline In perce & ntage & 1.01 & 47.62 & 0.45 & 3.77 & 47.15 & 100,00 \\
\hline 27 & $\begin{array}{l}\text { Ilyina Gora } \\
\text { village }\end{array}$ & 3 & 111 & 60 & 776 & 136 & 1086 \\
\hline In perce & ntage & 0.28 & 10.22 & 5.52 & 71.45 & 12.52 & 100,00 \\
\hline 98 & $\begin{array}{l}\text { Kanzanavolok } \\
\text { with villages }^{\mathrm{a}}\end{array}$ & 31 & 498 & 454 & 116062 & 20343 & 137388 \\
\hline In perce & ntage & 0.02 & 0.36 & 0.33 & 84.48 & 14.81 & 100,00 \\
\hline $\begin{array}{c}97, \\
99-105, \\
107, \\
106 \\
\end{array}$ & $\begin{array}{l}\text { State owned land } \\
\text { and hayfields of } \\
\text { various villages, } \\
\text { Ilyinski pogost }\end{array}$ & 1 & 34 & 12 & 73 & 7 & 127 \\
\hline & In percentage & 0.79 & 26.77 & 9.45 & 57.48 & 5.51 & 100,00 \\
\hline & Grand total & 141 & 2251 & 1055 & 339455 & 32601 & 375503 \\
\hline & Total in percentage & 0.04 & 0.60 & 0.28 & 90.40 & 8.68 & 100,00 \\
\hline
\end{tabular}

${ }^{\text {a }}$ See lists of villages in dachas 24 and 98 in the table 2.

Source: KEO, 4, 8 -8ob.

Almost all of this significant space, including the settlements themselves, village ploughfields, hayfields, and forests and wasteland, was distributed between just two dachas: 24 (measured in GMOG to amount to 217,741 desyatina and 1498 sazhen) and 98 (126,043 desyatina and 1954 sazhen). In modern measurements they comprised 374,073 hectares (99.6\%) of the whole region's territory. Dacha 24 was by far the largest, making up $63 \%$ of the total land. Respectively, dacha 98 took up the remaining share (ca. 37\%). Only 217 hectars (dachas 25 and 26 together) and 126 hectars (dachas 97, 99-107) were additionally allocated to the inhabitants of southern and northern parts of Vodlozerie in the form of so called state-owned lands and hayfields (which altogether amounted to only $0.1 \%$ of the total land). What draws our attention, though, is the fact that this additional land fund (almost 350 hectares taken together) included a significant share of ploughed fields - ca. $40 \%$. By contrast, in the principal dachas, which officially included the settlements themselves, the ploughed fields did not amount to even $1 \%(0.6$ and $0.4 \%$ respectively). 


\section{In conclusion: wasted social potential}

As evidenced in $P G M$ (see Figure 1), the traditional settlement structure in the vicinity of the Vodlozero lake was originally characterised by a pronounced cluster localisation. Only a few villages were located at a significant distance from the others: Okhtom-ostrov and Gumarnavolok on the western shore of Lake Vodlozero, Kalakunda on the river Ileksa, and Borovoi Porog and Vamski Porog on the river Vama.

A separate group was comprised of the villages located further to the northwest from Lake Vodlozero: Paezero, Yangozero, Kukamos-ozero, Egozero, Uzkozero, and Svetlozero/Zamoshie. All the others obviously gravitated towards each other and when seen on the map form clusters of settlements.

Having in mind this evident feature of the settlement pattern in Vodlozerie and particularly in the light of the discovered stability of this settlement structure, we are coming near to answering the question of what could objectively explain the unrealised social and demographic potential of this region, which started out at a high level and evidently grew even further from the end of the $18^{\text {th }}$ century until - and including - the first third of the $20^{\text {th }}$ century. A glance at the map is enough to suggest that average density of population in Vodlozerie, including on a zonal level, should have been exceptionally low even during the time of its greatest habitation. So called wasteland (neudobiya) was simply taking up too much space. Indeed, a simple calculation demonstrates that, based on the $G M O G$ records at the end of the $18^{\text {th }}$ century, average population density did not exceed 0.5 persons in the Kanzanavolok and 0.7 persons in the Kuganavolok zones, and making a regional average of 0.6 persons per square kilometer (see Table 5). The area of square kilometres of the region under study (see Figure 5-6) is computed using an electronic resource. ${ }^{70}$

Table 5. Density of population in Vodlozerie in the end of the $18^{\text {th }}-$ beginning of the $20^{\text {th }}$ century

\begin{tabular}{lcrcccc}
\hline Main settlement & Area in sq. & \multicolumn{5}{c}{ Population / Average population per sq. km } \\
\cline { 3 - 7 } \multicolumn{1}{c}{ zones } & $\mathrm{km}^{\mathrm{a}}$ & 1791 & 1873 & $1905^{\mathrm{b}}$ & $1926^{\mathrm{c}}$ & $1933^{\mathrm{d}}$ \\
\hline Kanzanavolok & 1525.15 & $973 / 0.6$ & $\bullet$ & $1332 / 0.9$ & $1215 / 0.8$ & $1145 / 0.8$ \\
Kuganavolok & 2315.49 & $1176 / 0.5$ & $\bullet$ & $1720 / 0.7$ & $2272 / 1.0$ & $2145 / 0.9$ \\
Total & 3840.64 & $2149 / 0.6$ & $2598 / 0.7$ & $3052 / 0.8$ & $3487 / 0.9$ & $3290 / 0.9$ \\
\hline
\end{tabular}

a Using electronic resource's tool to determine the size of the area; ${ }^{b}$ Kuganavolok zone includes two village communities: Kuganavolok and Pilmasozero; ${ }^{c}$ Pilmasozero rural council also includes Yangozero villages; ${ }^{\mathrm{d}}$ Kuganavolok zone includes three rural councils with centers in Kuganavolok, Pilmasozero and Chuyala respectively.

Source: KEO, 4, 8-8ob; EKP, 12ob, 28ob-31; Spisok 1873, 165-166, 180-181; Spisok 1905, 248251; Spisok 1926, 39-40, 102-104; Spisok 1933, 76-77.

\footnotetext{
${ }^{70}$ Černâkova at al., General'noe meževanie.
} 
Figure 5. Total area of the region of Vodlozerie shown in digitized map GMOG 1791



Source: as in Figure 2. 
Figure 6. The area of the dacha 98 (Kanzanavolok part of Vodlozerie) shown in digitized map GMOG 1791

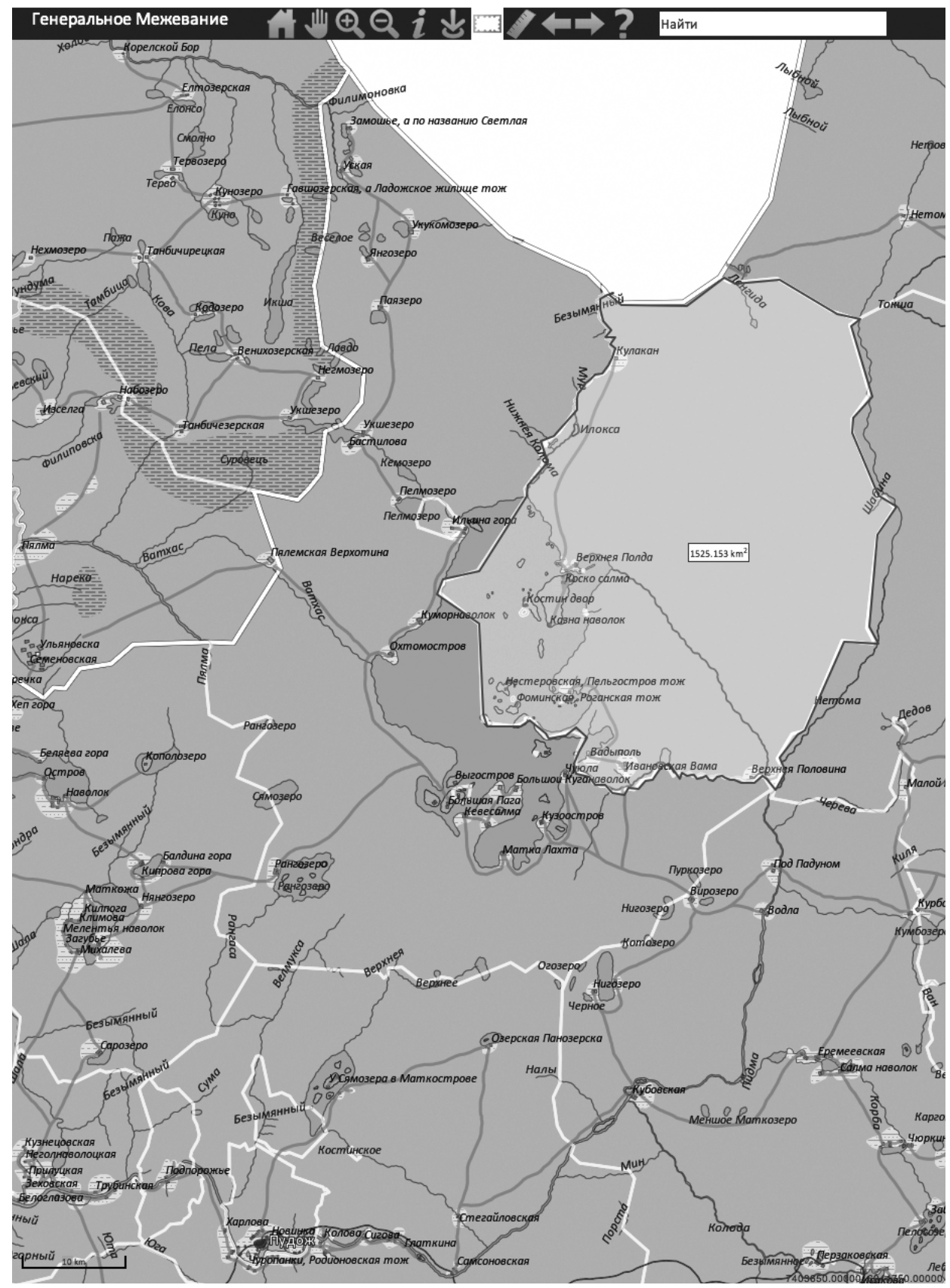

Source: as in Figure 2. 
The figures compiled in table 5 demonstrate that the population in Vodlozerie had increased by $42 \%$ during the hundred-odd years from the end of the $18^{\text {th }}$ century until the beginning of the $20^{\text {th }}$ century. While the Kanzanavolok population grew by more than one third, the number of people in Kuganavolok had almost doubled (37\% and $46 \%$ respectively). Thereafter this dynamic development was interrupted, as evidenced by obvious population decrease in the area to the northeast of Lake Vodlozero (by 117 people). Apparently, there was also an interregional migration of people from Kanzanavolok area to Kuganavolok, where the number of inhabitants continued to grow (plus 552 people).

One can only guess at what exact point the direction of development changed, as the time period between available statistical data (1905-1926) is too long. In addition, these years coincided with the deep social and political cataclysm of the establishment of Soviet rule as well as losses due to the Civil War and intervention. Furthermore, the local community was undoubtedly affected by the hardships and losses of the First World War, which preceded the Revolution and caused the mobilisation of the male population. One might think that the dramatic events affected the northern part of region to a greater extent than the south. The population growth in Kuganavolok zone continued no matter what and was so significant that it secured overall population increase in the whole region as recorded in 1926 (by 14\%). Population density in Kuganavolok doubled (from 0.5 to 1.0 person per sq. $\mathrm{km}$.), which can also be seen as evidence of the notion that southern Vodlozerie was ahead in its development during the first decade of Soviet rule. Although density of population in pre-revolutionary statistics was measured in sq. versta and not sq. kms., the error is not so significant as to make it impossible to compare with the result of our calculations $(1 \mathrm{sq}$. versta equals 1.14 sq. km.). According to the statistical data of 1892 the density of population in Pudozh county was up to 1.2 souls, which is „less by 3.9 souls than in the rest of the province". ${ }^{71}$ It should thus be noted that the density of population in Vodlozerie remained extremely low.

At the same time the areas of settlement clusters seem to have been much more densely populated and very likely approaching the level of relative overpopulation. Their inhabitants were often forced to use ploughed fields and hayfields that were very remote from their homes. Here is a historical illustration of the situation in the last decade of the $18^{\text {th }}$ century. The source defines dacha 97 as ,state-owned hayfields" and localises this area as "along the Vodla river, near the threshold and the Netoma river" ( po Vodle rechke opes' poroga i Netome rechke). The description evaluates this area as highly productive, which is very

${ }^{71}$ Ivan Blagoveŝenskij, "Narodonaselenie Oloneckoj Gubernii v 1892 godu”, Oloneckij Sbornik 3 (1894): 426. 
rare for Vodlozerie ("bad" was a more usual mark), and includes invaluable information about the owner: "Location on the left side of the Vodla river close by the mouth of the Netoma river on the right. Soil is oozy. Hayfields are sizable. Forest is suitable for firewood: spruce, birch and pine. The land is farmed by a peasant from Itomgora village on the condition of servage" ${ }^{72}$ In order to reach this land plot from Koskosalma (another name for Itomgora), one needed to travel on Lake Vodlozero to the mouth of the Vama river and then up the river until it merged with the Vodla. The land plot was located right there in the area between the Vodla and another river, the Netoma. Another route was to follow the Vodla river from the northeastern part of Lake Vodlozero (see Figure 1). In both cases it was not a short trip. Our electronic resource makes it possible for us to measure the distance with a "ruler tool". It turns out that following the first route described above, the peasant would have to travel a distance of $46.5 \mathrm{~km}$, while the alternative route was somewhat shorter $-\mathrm{ca} .31 \mathrm{~km} .{ }^{73}$

The evident stability of the settlement system shows that it was the only possible version of its development due to specific landscape and geographical conditions. The quantitative characteristics of the social potential of this region, presented above and analysed within several time periods and from different angles, convince us of the fact that spontaneous rationality, inherent for the traditional peasant community, justified itself over the centuries. Evidently, the use of natural resources was not at all predatory and left room for recreation of forest and meadow landscapes, renewal of fish to catch and natural hunting grounds in each of the established clusters of settlements.

We believe that a comprehensive analysis of settlement lists together with $G M O G$ materials ( $P G M$ - maps; $E K P$ and $K E O$ - descriptions) provide us with a key to the understanding of the limits of sustainable land management in this region. The fact that the share of ploughed fields was so much higher (ca. 40\%) in the additional state-owned areas (obrochnaya zemlya), which supplemented the main dachas, than the share of regular village fields (ca. $0.5 \%$ ), is considered to be weighty evidence that people of Vodlozerie actively utilised available natural resources and grounds for agriculture. Local adherence to slash-and-burn farming is once more confirmed indirectly, as it was the only method that could guarantee high yields of grain and vegetables in the studied period of time. ${ }^{74}$

Depopulation was bound to come as the balance of traditional agricultural practices was destroyed. It had first halted in the late 1920s and early 1930 s

${ }^{72}$ EKP, 28ob.

${ }^{73}$ Černâkova at al., General'noe meževanie.

${ }^{74}$ Vasilij Gomilevskij, "S krajnego severa Evropejskoj Rossii”, Sel'skoe Hozâjstvo i Lesovodstvo 128 (1878): 51. 
with the forced collectivisation of agriculture in the Pudozh region. In its course coercive methods were actively applied to local peasantry. The fact that the number of inhabitants had decreased significantly (197 persons) in just seven years (1926-1933) can be seen as evidence that Vodlozerie was also affected by the wave of political repressions. It is a known fact that in 1931 a "special settlement" was established on the island of Goltsy close to Pudozh coast of Lake Onego. More than 200 dispossessed peasant families were sent there from all over Karelia. ${ }^{75}$ Vodlozero inhabitants were also not spared the hardships of the two wars that would come one after another: the Finnish War and the Great Patriotic War. Peasant families had lost their men-breadwinners and sons-workers and were then doomed, together with their desolate land, the specific landscape of which had always required exceptionally well thought out labour efforts and a readiness to conquer great distances in order to secure subsistence of local village communities.

\section{Acknowledgments}

This work is financially supported by the Ministry of Education and Science of the Russian Federation within the budget theme N 33.1162.2014/K in the framework of the project part of the State assignment in the field of scientific activity.

\section{Sources}

\section{Primary sources}

Administrativno-territorial'noe delenie Onežskogo rajona Arhangel'skoj gubernii. Accessed 21.05.2016. http://www.onegaonline.ru/html/dz2/seetext.asp?kod=540.

Ėkonomičeskie kameral'nye primečaniâ k kartam General'nogo Meževaniâoloneckoj gubernii: Pudožskij uezd, $1791 \mathrm{~g}$. Rossijskij gosudarstvennyj arhiv drevnih aktov. F. 1355. D. 922. L. 1-44.

Kratkie èkonomičeskie opisaniâ k kartam General'nogo meževaniâ Oloneckojgubernii: Pudožskij uezd, $1791 \mathrm{~g}$. Rossijskij gosudarstvennyj arhiv drevnih aktov. F. 1355. D. 921. L. 1-14.

Plany General'nogo Meževaniâ Pudožskogo uezda Oloneckoj gubernii. Rossijskij gosudarstvennyj arhiv drevnih aktov. F. 1356. D. 3352-3361.

\section{Secondary sources}

Blagoveŝenskij, Ivan. "Narodonaselenie Oloneckoj Gubernii v 1892 godu”. Oloneckij Sbornik 3 (1894).

\footnotetext{
${ }^{75}$ Nikolaj Korablev, "Pudož'e - drevnij kraj za Onežskim ozerom: Istoričeskij očerk”, Sever 3-4 (2010): 162.
} 
Blagoveŝenskij, Ivan, ed. Spisoknaselennyh mest Oloneckoj gubernii po svedeniâm za 1905 god. Petrozavodsk 1907.

Červâkov, Oleg V., ed. Nacional'nyj park «Vodlozerskij»: Prirodnoe raznoobrazie ikul'turnoe nasledie. Petrozavodsk: Karelian Scientific Centre, 2001.

Kulikov, Vâčeslav, ed. Prirodnoe i kul'turnoe nasledie Vodlozerskogo nacional'nogo parka. Petrozavodsk 1995.

Kuznecova, Valentina, Boris Putilov, ed. Pamâtniki russkogo fol'klora Vodlozer'â: Predaniâ i bylički. Pertozavodsk 1997.

Ogorodnikov, Evlampij, ed. Spiski naselennyh mest Rossijskoj imperii po svedeniâm 1873 goda: Oloneckâ̂ guberniâ.

Potapov, Boris, ed. Spisok naselennyh mest Karel'skoj ASSR: po materialam perepisi 1926 g. Petrozavodsk, 1928.

Rossijskaâ imperiâ. Administrativno-territorial'noe delenie:1708-1917. Oloneckâ̂ guberniâ, 1775-1897 gg. Accessed 21.05.2016. http://www.nlr.ru/res/refer/r_imp/gub/ olon.html.

Spisok naselennyh mest: po materialam perepisi 1933 g. Petrozavodsk: Upravlenie narodnohozâjstvennogo učeta, 1935.

Trojnickij, Nikolaj, ed. Pervaâ vseobŝâ̂ perepis' naseleniâ Rossijskoj imperii 1897 g.: Oloneckaâ guberniâ. Moskva 1899.

\section{References}

Aarnio, Jouni, Kaskiviljelystä metsätöihin: tutkimus Pielisjärven Kruununmetsistä ja kruununmetsätorppareista vuoteen 1910. Joensuu 1999.

Âkubova, Tat'âna, Anna Krûkova. "Territorial'nyj brending kak instrument razvitiâ regiona”. Molodoj Učenyj, 21 (2014). Accessed 2.09.2016. http://moluch.ru/archive/80/14255.

Aver'ânov, Konstantin, “Vodlozer'e - Zapovednyj kraj russkogo Severa”. Trudy Instituta Rossijskoj Istorii 9 (2010).

Černâkova, Irina et al. General'noe meževanie Oloneckoj gubernii: Kartografičeskâ̂ spravočno-informacionnaâ Sistema. Accessed 21.05.2016. http://maps.karelia.ru/ mez.

Černâkova, Irina. "Vodlozer'e - poselenčeskie landšafty i social'nyj potencial v svete istoriko-geografičeskih dannyh konca XVIII veka”. CARELiCA 1 (2013): 20-21. Accessed 21.05.2016. http://carelica.petrsu.ru/2013/Chernyakova_1.pdf.

Černâkova, Irina, Olli-Pekka Tikkanen, Rajmo Hejkkilâ. Starye dokumenty i sovremennoe sotrudničestvo $v$ issledovanii rannej istorii okružaûsejej sredy v Karelii, 61-65. Materialy V meždunarodnoj konferencii po istoričeskoj geografii (18-21 maâ 2015 g.). Sankt_Peterburg 2015.

Cvetkova, Evgeniâ. Fol'klornaâ bylička Vodlozer'â: koldovstvo i magičeskâ̂ tradiciâ. Moskva 2014. Accessed 2.09.2016. http://www.ruthenia.ru/folklore/au_tsvetkova1. htm. 
Ericsson, Staffan, Lars Östlund, Anna-Lena Axelsson. "A forest of grazing and logging: Deforestation and reforestation history of a boreal landscape in central Sweden". New Forests 19 (2000): 227-240.

Gomilevskij, Vasilij. “S krajnego severa Evropejskoj Rossii”. Sel'skoe Hozâjstvo i Lesovodstvo 128 (1878).

Haruzin, Nikolaj. "Iz materialov, sobrannyh sredi krest'ân Pudožskogo uezda”. Oloneckij Sbornik 3 (1894): 306-307.

Haruzina, Vera. Na Severe: putevye vospominaniâ. Moskva 1890.

Heikinheimo, Olli. Kaskiviljelyksen vaikutus Suomen metsiin. Doctoral dissertation. Helsinki: Keisarillinen Aleksanterin yliopisto, 1915.

Holtta, Harri, Olli-Pekka Tikkanen, Irina Chernyakova, Raimo Heikkila. "Reflections of cultural history in the forest landscapes of Western White Sea Karelia". Trudy Gosudarstvennogo Prirodnogo Zapovednika "Kostomukšskij” 1 (2015): 183-186.

Korablev, Nikolaj. "Pudož'e - drevnij kraj za Onežskim ozerom: Istoričeskij očerk". Sever, 3-4 (2010).

Kûster, Hansjorg. Istoriâ lesa. Vzglâd iz Germanii. Sankt Peterburg 2012.

Lehmann, Albrecht. Von Menschen und Bäumen. Die Deutschen und ihr Wald. Hamburg 1999.

Loginov, Konstantin. Istoričeskaâ spravka o poseleniâh Vodlozer'â. Accessed 21.05.2016. http://vodlozero.nubex.ru/ru/nauka/issledovanie-istorii/istoricheskaya-spravka.

Loginov, Konstantin. Ètnolokal'naâ gruppa russkih Vodlozer'â. Moskva 2006.

Loginov, Konstantin. K probleme ètnokul'turnogo razvitiâ Srednego Poileks'â i Severnogo Priileks'â. Accessed 21.05.2016. http://folk.pomorsu.ru/index.php?page=opensource/27.

Loginov, Konstantin. Tradicionnyj žiznennyj cikl russkih Vodlozer'â: obrâdy, obyčai ikonflikty. Moskva 2010.

Lojter, Sof'â. “Ob ètnolokal'noj fol'klornoj tradicii Vodlozer'â”. Râbininskie Čteniâ, 2015. Accessed 2.09.2016. http://kizhi.karelia.ru/library/ryabininskie-chteniya-2015/1570. html.

Radkau, Joachim. Holz. Wie ein Naturstoff Geschichte schreibt. München 2007.

Radkau, Joachim. Priroda i vlast': Vsemirnaâ istoriâ okružaûŝej sredy. Moskva 2014.

Sokolov, Boris. "Poèziâ Vodlozera: Iz zapisok issledovatelâ". Čitatel' i Pisatel' 35 (1928).

Tikkanen, Olli-Pekka, Irina Chernyakova. "Past human population history affects current forest landscape sturcture of Vodlozero National Park, Northwest Russia". Silva Fennica 48 (2014). Accessed 21.05.2016. https://www.researchgate.net/publication/279079261_Past_human_population_history_affects_current_forest_landscape_structure_of_Vodlozero_National_Park_Northwest_Russia. 


\section{Summary}

The article presents a comparative evaluation of quantitative evidence of the living conditions in the Vodlozero region in northern Russia collected in five time periods $(1791,1873,1905,1926,1933)$ on the basis of the General Land Survey (Generalnoe Mezhevanie of Olonets Gubernia - GMOG), reintroduced into historical research practice, and a thorough examination of the lists of known settlements. Based on the information about the number of households and the dynamics of their habitability over time, as well as on the data pertaining to economic activities of the region's inhabitants, the author shows the increase of regional potential for social and demographic development from the end of the $18^{\text {th }}$ century until the first third of the $20^{\text {th }}$ century, which enabled the local peasant community to survive through the political upheavals of the first quarter of the $20^{\text {th }}$ century. By showing how the established traditional economic and social practices had evolved over centuries and ensured the sustainability of human and economic resources specific to the natural landscape of the Vodlozero area, the paper offers a retrospective reconstruction of the specifics of the extent of human intervention with nature, as well as social consequences of this process in the long run.

Keywords: Vodlozero area, General Land Survey (GMOG), cultural and historical landscape, settlement patterns and land use, population density, mean household size, the desolation of the region, the untapped social potential

\section{Wodłoziero (Rosja północno-wschodnia): miniony potencjał społeczny w kontek- ście danych historycznych i krajobrazu geograficznego}

\section{Streszczenie}

W artykule przedstawiono ocenę porównawczą warunków bytowych w regionie Wodłoziera w pięciu przedziałach czasowych $(1791,1873,1926,1933)$, opartą o wyniki Generalnego Badania Geodezyjnego (GMOG) oraz szczegółową rewizję list istniejących osad. Na podstawie danych o liczbie gospodarstw oraz informacji odnoszących się do dynamiki przemian ich ogólnych warunków mieszkalnych i sposobów pozyskiwania zasobów życiowych przez mieszkańców Wodłoziera, ukazano długofalowe tendencje rozwoju potencjału społecznego i demograficznego regionu od końca XVIII wieku do pierwszego kwartału wieku XX. Poprzez ukazanie przemian, jakim ulegały tradycyjne praktyki społeczne i gospodarcze w długim trwaniu, możliwa była rekonstrukcja specyficznych elementów interakcji człowieka ze środowiskiem naturalnym oraz ich konsekwencje społeczne.

Słowa kluczowe: region Wodłoziera, Generalne Badanie Geodezyjne (GMOG), krajobraz kulturowy i historyczny, tradycyjne osadnictwo regionalne i użytkowanie gruntów, gęstość zaludnienia, średnie zaludnienie gospodarstwa domowego, niewykorzystany potencjał społeczny 